Copyright ( ) 2016 SCAD Independent

All Rights Reserved

Printed in the Indonesia
Jurnal Ilmiah Peuradeun

Vol. 4, No. 3, Sep 2016

\title{
MULTICULTURALISM AS AN ALTERNATIVE A CULTURAL ORIENTATION TO EDUCATION IN THE ASPECT OF CULTURE AS THE AXIOLOGICAL FOCUS
}

\author{
1Rinat Suzanne and ${ }^{2}$ Liana Nathalie \\ ${ }^{1}$ School of Education, Hebrew University \\ ${ }^{2}$ School of International and Public Affairs, Columbia University \\ Email:nathalie.liana@columbia.edu
}

Received: May 10, 2016

Accepted: Aug 23, 2016

Published: Sep 28, 2016

Article Url: https:/ /journal.scadindependent.org/index.php/jipeuradeun/article/view/111

\begin{abstract}
Multiculturalism occurs naturally when a society is willing to accept the culture of immigrants. Multiculturalism has been defined as a method whereby culturally diverse groups are accorded status and recognition, not just at the individual level, but in the institutional structures of the society. Multiculturalists' perspectives have had a deep influence in the social sciences, and particularly in the field of education. Although it aims to improve society, multiculturalism has been criticized for adopting an essentialist approach to culture, because the calling for the appreciation and recognition of cultural variety. To achieve a situation in which culture has no exclusive value requires reevaluation of the concepts of culture and identity as accepted in the West over the past few centuries, examining epistemological and ontological conceptions and how they shape political and social organizations reflected in the nation-state. Just as culture is soft, permeable and dynamic, so too is the cultural self and its identity. If multiculturalism seeks a solution to distinctions that engender problems in a modern world in which many cultures are situated in one social space, we maintain that such distinctions are problematic and even erroneous. Modernity did not give rise to a multiplicity of cultures but rather to extensive cultural and social variation.
\end{abstract}

Keywords: Multiculturalism, Cultural, Orientation, Education 


\section{A. Introduction}

Multiculturalism occurs naturally when a society is willing to accept the culture of immigrants (with, ideally, immigrants also willing to accept the culture of the land to which they have come). A distinction should be drawn between multiculturalism that occurs simply due to the absence of a single enforced culture, and multiculturalism which is endorsed and actively encouraged by the government; this is often referred to as state multiculturalism (Wiki, 2015).

Kenan Malik (2010) states that "The experience of living in a society transformed by mass immigration, a society that is less insular, more vibrant and more cosmopolitan, is positive" but contrasts this with the political process of multiculturalism, which "describes a set of policies, the aim of which is to manage diversity by putting people into ethnic boxes, defining individual needs and rights by virtue of the boxes into which people are put, and using those boxes to shape public policy".

In reality, there is a spectrum between a monoculture where everyone is exactly the same and the negative stereotype of multiculturalism where a society is totally divided into separate ethnic communities who never associate. In any actual society, people will mix and associate with those of other races/cultures, while also keeping some kind of social or cultural identity (e.g. based on religion, ethnic group, local area, sport team, gang affiliation, goth/punk/skin/emo/etc subculture...). Complaints about multiculturalism usually arise when people encounter members of another subgroup but feel they are mixing too little; complaints about forced assimilation when people are forced to associate and compromise too much.

Multiculturalism describes the existence, acceptance, and/or promotion of multiple cultural traditions within a single jurisdiction, usually considered in terms of the culture associated with an aboriginal ethnic group and foreigner ethnic groups. This can happen when a jurisdiction is created or expanded by amalgamating areas with two or more different cultures (e.g. French Canada and English Canada) or through immigration from different jurisdictions around the world (e.g. Australia, Canada, United States, United Kingdom, and many other countries). 
In addition, multiculturalism has been defined as a method whereby culturally diverse groups are accorded status and recognition, not just at the individual level, but in the institutional structures of the society (Parekh, 2002). Moreover, multiculturalism involves the endorsement of harmonious and constructive relationships between culturally diverse groups (Cashmore, 1996). Multiculturalists perspectives have had a deep influence in the social sciences, and particularly in the field of education (Phillion, 2002; Phillion, $\mathrm{He}$, \& Connelly, 2003), where it is on its way to becoming a well-established sub-discipline sustained by a wide variety of theoretical knowledge, practical guidelines and curricula (Banks, 1994; Bennette, 1990; Bloom, 1987; D'Souza, 1992; Ravitch, 1990; Schlesinger, 1991; Sleeter \& Grant, 1988). Still the minimal literature on the impact of multicultural educational reform has yielded its fair share of debate and criticism and has not always been encouraging (Freeman, 2000; Hanna, 1994; Lustig, 1997; Whitehead \& Wittig, 2004).

\section{B. Criticism and Challenge of Multiculturalism in the world}

It is worth noting that the reification of culture is closely linked with the development of the nation-state. Elias (1998) and Williams (1961) shed light on the reciprocal relations between these two phenomena, a process that includes transition from expression and representation of culture as open and constantly growing, through interpersonal and group encounters, to its conception and presentation as an organized, wellformed, closed and fixed system of cultural items or objects, complete and autonomous in themselves.

Although it aims to improve society, multiculturalism has been criticized for adopting an essentialist approach to culture, because the calling for the appreciation and recognition of cultural variety. Critics say that it misses the mark by assuming that each group has a defined number of participants that become similar to one another and different from other groups by virtue of the circumstances of their birth or early processes of socialization (for example, a Jew is a Jew and not a Christian; Chinese are Chinese and not French).

These complete objects have been used to foster unity among inhabitants of a given nation-state's territory, thereby neutralizing local- 
regional and linguistically variant sub-communities that the state seeks to incorporate into the national group. The patterns represented by the nation-state required an operative apparatus for application, supervision and regulation that accords its owners active, effective and exclusive control over the means of violence in society (Giddens, 1991; Smith, 1998). As Gellner (1997) has suggested, it was the educational system that provided the application system.

In its most extreme formula, multiculturalism assumes that each person has one legitimate and authentic culture whose legitimacy is acquired by biological heredity and from whence the demand for and right to ownership is derived by its heirs. Thus, multicultural perspectives tend to reify culture.

Our key question therefore is the following: How wills multiculturalism accord equality to citizens? The answer is indecisive at best; for it appears that cultural discourse rewrites and reshapes the race discourse that prevailed following the development of philosophy and science in the nineteenth and early twentieth century's (Haraway, 1991). The context of cultural rhetoric may mellow racism, but the outcome, like that of race theory, assigns people to a static birthplace category from which there are no escape. As such, multicultural discourse does not provide any innovative solution to inequality. Just as race theory explains the "inferior" economic and social class of "marginal' groups in society in terms of their racial affiliation, multicultural conceptions explain it in terms of cultural affiliation (Malik, 1996; Varenne \& McDermott, 1998).

\section{Multiculturalism Education and Integrated Schools in Israel}

To illustrate this critique, I offer some insights from my own research on integrated bilingual Palestinian-Jewish schools in Israel followed by some theoretical remarks regarding possible change. Demographically, Israel segregates its Palestinian and Jewish populations almost completely in terms of education. There are only four integrated schools in Israel. These schools serve today a population of approximately 1300 children and are expanding to serve K-12 students. Their aim is to 
further mutual understanding, recognition and coexistence among the two groups which for the last 100 years have been involved in what has come to be known as an intractable conflict (Bar-Tal, 1998). To achieve their aim, these schools are committed to bilingual (Arabic/Hebrew) education and a multicultural educational approach which allows each participant to get to know more about the 'other's' culture while strengthening his/her individual and collective sense of identity and belonging (for a description and analysis of these initiatives, see Bekerman, 2003a, 2003b, 2004, 2005a, 2005b; Bekerman \& Horenczyk, 2004; Bekerman \& Maoz, 2005; Bekerman \& Shhadi, 2003).

Since the initiative is committed to sustaining educational institutions in which Palestinians and Jews are approximately equally represented, each family accepted to the system needs to be clearly identified as belonging to one or the other group. However, this is not always easy. The schools sometimes serve as a refuge for families who have dared to break social taboos against intermarriage, and determining the classification of a child from a mixed family is not always easy. There are other confusions as well: for example, Armenian families who decide to send their children are, for some incomprehensible reason, counted as Palestinian.

In the multiple interviews that I conducted with parents and teachers, all expressed their commitment to strengthening the children's sense of belonging to their ethnic and religious groups. It was emphasized that getting to know each other was important but that this should not imply giving up "our own roots and traditions." Practically, this increases the complexity of the situation because it implies focusing on cultural aspects that for the most part represent religious traditions and stereotyped cultural artifacts. In fact, most parents of children attending the integrated schools are not very religious. As a general rule the Jewish parents are not religious at all, and though it is more difficult to speak about the Palestinian parents as secular, at the most they are traditionalists and not very religious. The teachers are very similar to the parents, but despite their personal preferences, they all seem to find solace in religious and stereotyped cultural artifacts from the perceived dangers of assimilation rising from the integrated adventure. 
Thus, paradoxically, an educational sphere meant to soothe national conflicts finds itself emphasizing cultural differences. Even if, for a moment, we find this chosen direction desirable, we should ask if that which is offered in terms of religious or cultural artifacts does indeed do justice to cultural traditions that are over one thousand years old. I doubt the answer could be affirmative: can shallow representations of Hanukkah or Idel-Fiter, or Rosh Hashanah and Ramadan, or hummus, pith, and levivot do justice to two old and revered traditions which have been responsible for the development of worldviews which, through the ages, have produced profound literary and scientific products that till today feed the imagination of a thinking humanity? But the building bricks of these civilizations are nowhere to be found in the school curriculum--only shadows of them, in the shape of truncated holy texts or cuisine recipes, make an appearance on the school scene.

Still, most of the stakeholders involved in the initiative seem to be happy with the outcomes. Parents, for the most part, find in the emphasis given to cultural issues the justification to explain to their own communities and families, who might be suspicious of their decision to send their children to these schools, why sending their children to an integrated educational initiative is not necessarily a step towards assimilation.

Parents sending their children to the integrated initiative belong to the middle and upper-middle socioeconomic strata, and their main interests seem to rest with the social mobility they expect these schools to afford their children. Though in their interviews they usually justify their participation in the integrated schools by liberal, ideological, and peace seeking statements, parents also make it clear that their main interest is the successful education of their children which will allow them to join good-quality institutions of higher education in an increasingly global world. Though Jewish parents could easily find other options, they seem to be happy to allow their children to support their ideological liberal stand through their participation in the integrated schools. On the other hand, Palestinian parents know that Israel's present reality affords them few educational opportunities within the segregated Arab educational 
system and see in the integrated option a way out of these limitations. The short description above should help us question whether these initiatives are succeeding in what they set out to achieve and, despite their good intentions, if they can achieve their aims given the limitations.

The example illustrated above resembles the ones described in the multicultural critical literature I cited in the introduction. The problems described therein are not specific to contexts suffering from intractable conflict. Though not much research has yet been published regarding the specifics of multicultural educational efforts in conflict-ridden societies, from my experience with multiple educational NGOs (in Israel, the Palestinian Territories, Cyprus, Northern Ireland, and BosniaHerzegovina) it seems fair to say that multicultural educational initiatives generally tend to replicate the approach criticized above.

Traditionally these approaches, which are based on contact hypothesis perspectives (Allport, 1958), adopt the discourse of 'enhancing' awareness of the many different cultures or lifestyles that exist, even in a classroom, or enhancing the understanding of vital connections between a language and a culture, or enhancing the recognition of alterity. What is most outstanding is that this approach never seems to uncover the socioeconomical-political realities that dominate conflict. The discourse of 'enhancing cultural sensibilities' seems to serve dominant interests well. We should question if this discourse can effectively serve the victims of conflict.

\section{A Cultural Orientation to Education (Alternative Approaches)}

A critical analysis of the above-mentioned orientation might begin by offering as an alternative a cultural orientation to education, one which starts at the periphery and critically approaches culture, not as a reified concept, but as one in the making.

Anthropological perspectives on culture offer such an opportunity. Franz Boas (Boas, 1940) strove to divest cultural considerations from any attention to race whatsoever, arguing against the prevailing conception of culture as a kind of separate and unique monad. Margaret Mead (Mead, 
1942), emphasized the importance of acculturation, noted that a newborn can become a member of any group irrespective of its biological cultural heritage or the extent of variance between target and source group. As all cultures are shown to be interconnected and active in a reciprocally self nourishing system, the excellence of any particular culture cannot be attributed to its associated nation.

Affiliation with a group is not a matter of identity but of identification (Carbaugh; Varenne \& McDermott, 1998) that develops along with human activity and is shaped and reinterpreted as a kind of cultural activity conducted together with one's partners and neighbors. In different historical and social contexts, the same behavioral pattern may give rise to different kinds of group identification. According to this point of view, being, say, a Jew or an Arab is not destiny but achievement, attained with the permission of all partners in efforts carried out at given moments in history. We reiterate that this complex admixture is imparted through the vigorous social activity occurring in a particular place. "Arab" and "Jew" are not characteristics in people's minds but the results of work accomplished in the contexts in which these characteristics exist, thus "Arab" and "Jew," if at all characteristics, are in the world, not in the head.

If multiculturalism seeks a solution to distinctions that engender problems in a modern world in which many cultures are situated in one social space, we maintain that such distinctions are problematic and even erroneous. Modernity did not give rise to a multiplicity of cultures but rather to extensive cultural and social variation. The acceptance or rejection of one cultural shade or another has never been part of an all-ornothing package deal demanding total rejection or total assimilation. Those who claim otherwise do not portray the historical world realistically but rather perpetuate an ideological school that had previously served identity and culture with the purpose of consolidating priority for the ruling authority using those same tools (Hall, 1996; Zizek, 1997) to identify those who resemble them and incriminate all others. The ruling group's reasoning is obvious: Accounting for otherness is preferable to accountability for it. 


\section{E. Conclusion}

Cultural development is consolidated through translation - an act that from the outset does not address the intercultural sphere alone but also accounts for all communicative activity between human beings, even those who ostensibly belong to the same culture (Becker, 1995; Ortega-y-Gasset, 1957). The theoretical developments to which we alluded perceive culture as a whirlpool more than as an island. Cultural identities reinforce their unity not by relying on meanings from the past but by reconstructing and reinterpreting cultural materials accessible to all (Bauman, 1999). Consequently, the arguments propounded in this article should not be perceived as an appeal against commitment to one community or another or against differentiation among groups - but rather only against their conception as possessing any exclusive character.

To achieve a situation in which culture has no exclusive value requires reevaluation of the concepts of culture and identity as accepted in the West over the past few centuries, examining epistemological and ontological conceptions and how they shape political and social organizations reflected in the nation-state. Just as culture is soft, permeable and dynamic, so too is the cultural self and its identity.

Furthermore, the difficulties encountered have nothing to do with the linguistic constraints that preclude our understanding of one cultural language or another. The impossibility of grasping the precise meaning of a given symbol is a universal principle imprinted in all human beings. Hence, the cultural approach that undermines "enlightenment" is the one that posits that cultures exist within clearly delineated boundaries that are entitled to recognition (political, social or otherwise). "Enlightenment" will be achieved only through a cultural conception that demands equality because all human beings are entitled to choose what they wish to be. Only such conditions accord the appropriate universal meaning in support of variation.

Finally, we should recall that most of the world's problems hunger, disease, poverty, pollution, displacement and the like - do not originate in the term "culture" in its axiological or symbolic sense but rather in culture as work or human interaction. It is this aspect of culture that ought to constitute the focus for solutions. 


\section{Bibliography}

Bakhtin, M. M. (1984). Problems of Dostoersky's poetics (C. Emerson, Trans.). Mineapolis: University of Minessota Press.

Banks, J. A. (1994). An introduction to multicultural education. Boston: Allyn and Bacon.

Bar-Tal, D. (1998). Societal Beleifs in Times of Intractable Conflict: The Israeli Case. International Journal of Conflict Management, 9, 22-50.

Bauman, Z. (1999). Culture as praxis. London: Sage.

Becker, A. L. (1995). Beyond Translation Essays toward a Modern Philology. Ann Arbor: The University of Michigan Press.

Bekerman, Z. (2003a). Never free of suspicion. Cultural Studies $<>$ New Methodologies, 3(2), 136-147.

Bekerman, Z. (2003b). Reshaping Conflict through School Ceremonial Events in Israeli Palestinian-Jewish Co-Education. Anthropology \& Education Quaterly, 34(2), 205-224.

Bekerman, Z. (2004). Multicultural approaches and options in conflict ridden areas: Bilingual Palestinian-Jewish education in Israel. Teachers College Record, 106(3), 574-610.

Bekerman, Z. (2005a). Are there children to educate for peace in conflictridden areas? A critical essay on peace and coexistence education. Intercultural Education, 16(3), 235-246.

Bekerman, Z. (2005b). Complex contexts and ideologies: Bilingual education in conflict-ridden areas. Journal of Language Identity and Education, 4(1), 1-20.

Bekerman, Z., \& Horenczyk, G. (2004). Arab-Jewish Bilingual Coeducation in Israel: A Long-Term Approach to Intergroup Conflict Resolution. J Social Issues, 60(2), 389-404.

Bekerman, Z., \& Maoz, I. (2005). Troubles with Identity: Obstacles to coexistence education in conflict ridden societies. Identity, 5(4), 341-358.

Bekerman, Z., \& Shhadi, N. (2003). Palestinian Jewish bilingual education in Israel: Its influence on school students. Journal of Multilingual and Multicultural Development, 24(6), 473-484.

Bennette, C. I. (1990). Multicultural education: Theory and practice (2 ed.). Bostob: Allyn \& Bacon. 
Bloom, A. (1987). The closing of the American mind. New York: Simon \& Schuster. Boas, F. (1940). Race, language, and culture. New York: Free Press.

Carbaugh, D. (1996). Situating selves: The communication of social identities in American scenes. Alnaby: SUNY Press.

Cashmore, E. (1996). Dictionary of race and ethnic relations. London, UK: Routledge.

Elias, N. (1998). Civilization, culture, identity: "Civilization" and "Culture": Nationalism and Nation State Formation': an extract from the Germans. In J. Rundell \& S. Mennell (Eds.), Classical Readings in Culture and Civilization (pp. 225-240). New York: Routledge.

Freeman, R. (2000). Contextual challenges to dual-language education: A case study of a developing middle school program. Anthropology $\mathcal{E}$ Education Quaterly, 31(2), 202-229.

Gellner, E. (1997). Nationalism. New York: New York University Press.

Giddens, A. (1991). Modernity and self identity. Stanford CA: Stanford University Press.

Hall, S. (1996). Introduction: Who needs 'Identity'? In S. Hall \& P. du Gay (Eds.), Questions of Cultural Identity (pp. 1-18). London: Sage.

Hanna, J. L. (1994). Issues in supporting school diversity: Academiocs, social relations, and the arts. Anthropology \& Education Quaterly, 25(1), 66-85.

Haraway, D. J. (1991). Simians, Cyborgs, and Women: The Revition of Nature. New York: Routledge.

Haynes, J. (2015). Religion in Global Politics: Explaining Deprivatization. Jurnal Ilmiah Peuradeun, 3(2), 199-216.

Karibi, R. A. I. N. (2015). Religion, Human Rights and the Challenges of Freedom. Jurnal Ilmiah Peuradeun, 3(1), 39-54.

Levi-Strauss, C. (1955). Tristes tropiques (J. Russell, Trans.). New York: Atheneum.

Lustig, D. F. (1997). Of Kwanzaa, Cinco de mayo, and whispering: The need for intercultural education. Anthropology \& Education Quaterly, 28(4), 574-592.

Lvina, E. (2015). The Role of Cross-Cultural Communication Competence: Effective Transformational Leadership Across Cultures. Jurnal Ilmiah Peuradeun, 3(1), 1-18. 
Malik, K. (1996). The meaning of race: Race, history and culture in Western society. Houndmills: Macmillan.

Malik, Kenan. (2010), Multiculturalism undermines diversity. https://www.theguardian.com/commentisfree/2010/mar/17/multi culturalism-diversity-political-policy

Mead, M. (1942). And keep your powder dry: An anthropologist looks at America. New York: W. Morrow.

Ortega-y-Gasset, J. (1957). Man and people. New York, NY: Norton.

Parekh, B. (2002). Rethinking multiculturalism: cultural diversity and political theory. Cambridge, MA: Harvard University Press.

Phillion, J. (2002). Narrative multiculturalism. Journal of Curriculum Studies (34), 265-279.

Phillion, J., He, M. F., \& Connelly, F. M. (2003). Experiential Approaches to the Study of Multiculturalism in Education: Introduction to the Special Series on Multiculturalism in Curriculum Inquiry. Curriculum Inquiry, 33(4), 341-342.

Ravitch, D. (1990). Diversity and Democracy: Multicultural education in America. American Educator, 14, 16-20.

Schlesinger, A. (1991). The desuniting of America: Reflections on a multucultural society. Knoxville, TE: Whittle Direct Books.

Sleeter, C. E., \& Grant, C. A. (1988). Making choices for multicultural education: Five approaches to race, class and gender. Columbus, $\mathrm{OH}$ : Merrill.

Smith, A. D. (1998). Nationalism and Modernism. London: Rutledge.

Varenne, H., \& McDermott, R. (1998). Successful Failure: The Schools America Builds. Colorado: Westview Press.

Whitehead, K. A., \& Wittig, M. A. (2004). Discursive management of resistance to a multicultural education programme. Qualitative Research in Psychology, 1(4), 267-284.

Williams, R. (1961). Culture and society, 1780-1950. Hardmondsworth: Penguin Books.

Zizek, S. (1997). The abyss of freedom/ Ages of the world(The Body, in Theory - Histories of Cultural Materialism) (J. Norman, Trans.). Ann Arbor: Michigan University Press. 